\title{
Nuclear energy: Russia's international treaties with other EEU members
}

\author{
Olga Vladimirovna Glikman ${ }^{11}$, Aziza Ulugbekovna Nazarova $^{1}$, Alina Valeryevna Filippova ${ }^{2}$, \\ and Ekaterina Gennadyevna Minenkova ${ }^{3}$ \\ ${ }^{1}$ MGIMO MFA of Russia, Department of International Law, Moscow, Russia \\ ${ }^{2}$ MGIMO MFA of Russia, Department of World Electric Power, Moscow, Russia \\ ${ }^{3}$ MGIMO MFA of Russia, International Institute of Energy Policy and Diplomacy, Moscow, Russia
}

\begin{abstract}
The purpose of the study is to identify trends and compare the scope of multilateral and bilateral international legal regulation of relations between Russia and other Eurasian Economic Union members in the field of peaceful use of nuclear power (energy). The methodological basis of the research consists of general scientific and special legal methods. The application of these methods made it possible to subject the current national legislation in the field of nuclear energy to in-depth comparative legal analysis and to identify the prospects for its modernization. The result of the study was the absence of special provisions in the Treaty on the Eurasian Economic Union aimed at integration in the nuclear energy sector and the formation of a common nuclear energy market of the Eurasian Economic Union. The study's novelty lies in the authors' approach to the allocation and comparison of the scope and subject matter of existing international treaties of Russia with other Eurasian Economic Union members, regulating cooperation in the peaceful use of nuclear energy, which are not included in the Eurasian Economic Union law. According to the authors, despite the prospects and trends of forming the Eurasian Economic Union nuclear law noted by experts, Russia's bilateral international agreements with other Eurasian Economic Union members will continue to play a special role in regulating relations in the nuclear energy sector.
\end{abstract}

Keywords: nuclear energy, international treaties, Eurasian Economic Union

\section{Introduction}

International cooperation in the nuclear energy sector is a strategic direction for Russia. Rosatom state corporation ranks first in the world in terms of the largest portfolio of foreign projects [1].

Currently, international energy law is actively developing [2-4]. In international relations, the "geopolitical aspects of nuclear energy" are growing stronger [5]. International nuclear law was of particular interest to Soviet international lawyers $[6,7]$. In the research of modern Russian specialists, much attention is paid to energy cooperation

1* Corresponding author: glikman@mail.ru 
within the framework of the Eurasian Economic Union (EEU) [8-10], cooperation in the use of nuclear energy and the development of nuclear law [11-13]. However, there are no separate works devoted to the bilateral international agreements of the EEU members in the nuclear sector.

Despite the integration of the EEU members in the energy field, the formation and prospects for the development of the EEU energy law noted in studies, as well as the existing multilateral legal framework for regulating cooperation in the nuclear field within the framework of the IAEA and the CIS, bilateral international treaties play a special role in Russia's international relations with other EEU members in the nuclear field.

The development of international energy law is noted in the literature and practice. Based on the Treaty on the Eurasian Economic Union, cooperation among EEU members in the energy sector is developing, common EEU energy markets and the EEU energy law are being formed. At the same time, new bilateral international agreements between Russia and other EEU members in various energy sectors, including nuclear energy, continue to operate and are being concluded. According to the World Nuclear Association, there are 442 power units with a total capacity of $393 \mathrm{GW}$ in the world, of which 40 power units with an installed capacity of more than $30 \mathrm{GW}$ operate in the EEU (in Russia - 38, Armenia - 1, Belarus - 1).

The study's objective is to compare the scope and subject of legal regulation of the EEU legal norms and bilateral international agreements between Russia and other EEU members in the field of the peaceful use of nuclear energy. It is necessary to solve the following tasks to achieve the study's objective: to analyze the provisions of the Treaty on the Eurasian Economic Union, the sectoral bilateral international treaties of Russia, as well as the views of scientists and practitioners on the trends in the legal regulation of relevant issues.

\section{Methods}

The authors used the following methods of scientific knowledge to achieve the research objectives and solve the tasks set: general methods (analysis, synthesis, induction, deduction, analogy), as well as special methods (comparative legal and formal legal). The use of these methods allowed to subject the current national legislation in the field of nuclear energy to an in-depth comparative legal study and to identify the prospects for its modernization.

\section{$3 \quad$ Results and discussion}

The Treaty on the Eurasian Economic Union, 2014, provides for the formation of three common markets for the main energy resources: electricity, gas, oil, and petroleum products, i.e., not all types of energy resources and not the common energy market of the EEU as a whole [10]. Section XX of the Energy Treaty does not contain special provisions on nuclear energy and the formation of a common market for nuclear energy in the EEU. At the same time, the EEU members carry out multilateral cooperation in the nuclear field within the framework of the IAEA and the CIS (all EEU members participate in the CIS). Experts link the prospects for the development of cooperation between the EEU members in the nuclear energy sector directly with the creation (according to the plan by 2025) of the common electric power market of the EEU [9].

There is an opinion that it is necessary to develop an international EEU legal act that establishes a unified approach to the legal regulation of nuclear energy use [14]. The lack of the necessary level of law harmonization of the EEU members is considered an obstacle to integration in nuclear energy use [15]. Domestic experts suggest using the experience of 
Euratom as the first stage of integration in this area and creating a special body - EEUatom [9]. At the same time, foreign literature emphasizes that the attitude of the members of the European Union to nuclear energy has changed (most European states have abandoned the development of nuclear energy) and that the Treaty establishing Euratom is outdated and needs to be changed to take into account the current environmental, social and economic goals of the European Union [16].

Today, on the one hand, the EEU law is developing; experts note the emergence of the EEU energy law [8], the EEU nuclear law. On the other hand, the bilateral international agreements of the EEU members, which are not included in the EEU law under Article 6 of the Treaty, continue to play a special role in regulating cooperation in the nuclear sector. The relevant intergovernmental agreements of Russia (Table 1) are "the main legal instruments for creating favorable conditions for the entry of Russian nuclear technologies and services into the world market" [12].

Table 1. International treaties of the Russian Federation.

\section{International treaties of Russia and Armenia}

Agreement between the Government of the Russian Federation and the Government of the Republic of Armenia on the reactivation and recommissioning of the Armenian nuclear power plant of March 17,1994

Agreement between the Government of the Russian Federation and the Government of the Republic of Armenia on cooperation in the field of peaceful use of nuclear energy of September 25, 2000

Agreement between the Government of the Russian Federation and the Government of the Republic of Armenia on cooperation in the construction of new power units of a nuclear power plant in the territory of the Republic of Armenia of August 20, 2010

Agreement between the Government of the Russian Federation and the Government of the Republic of Armenia on cooperation in the field of nuclear safety of December 2, 2013

Agreement between the Government of the Russian Federation and the Government of the Republic of Armenia on cooperation in extending the life of Unit 2 of the Armenian Nuclear Power Plant of December 20, 2014

Agreement between the Government of the Russian Federation and the Government of the Republic of Armenia on granting the Government of the Republic of Armenia a state export credit to finance the work on extending the life of a nuclear power plant in the territory of the Republic of Armenia of February 5,2015

Agreement between the Government of the Russian Federation and the Government of the Republic of Armenia on early notification of a nuclear accident and exchange of information in the field of nuclear and radiation safety of October 7,2015

International treaties of Russia and Belarus

Agreement on the basic principles of cooperation in the field of peaceful uses of nuclear energy of June 26, 1992

Agreement between the Government of the Russian Federation and the Government of the Republic of Belarus on cooperation in the field of the peaceful use of nuclear energy of May 28, 2009

Agreement between the Government of the Russian Federation and the Government of the Republic of Belarus on cooperation on the import of irradiated and fresh highly enriched nuclear fuel from research reactors to the Russian Federation and the supply of fresh low-enriched nuclear fuel to the Republic of Belarus of October 8, 2010

Agreement between the Government of the Russian Federation and the Government of the Republic of Belarus on cooperation in the construction of a nuclear power plant on the territory of the Republic of Belarus of March 15, 2011; Protocols on Amendments of December 23, 2014, February 26, 2018, July 14,2020

Agreement between the Government of the Russian Federation and the Government of the Republic of Belarus on granting the Government of the Republic of Belarus a state export loan for the construction of a nuclear power plant in the territory of the Republic of Belarus of November 25, 2011; Protocols on Amendments of December 20, 2014, and May 25, 2015 
Agreement between the Government of the Russian Federation and the Government of the Republic of Belarus on cooperation in the field of nuclear safety of February 1,2013

Agreement between the Government of the Russian Federation and the Government of the Republic of Belarus on early notification of a nuclear accident and exchange of information in the field of nuclear and radiation safety of December 13, 2013

International treaties of Russia and Kazakhstan

Agreement between the Government of the Russian Federation and the Government of the Republic of Kazakhstan on cooperation in the field of peaceful use of nuclear energy of March 28, 1994

Agreement between the Government of the Russian Federation and the Government of the Republic of Kazakhstan on the integration of nuclear fuel cycle enterprises of July 6, 1998

Agreement between the Government of the Russian Federation and the Government of the Republic of Kazakhstan on scientific and technical cooperation in the framework of the development of the technical project of the International Thermonuclear Experimental Reactor of October 12, 1998

Agreement between the Government of the Russian Federation and the Government of the Republic of Kazakhstan on the establishment of the International Uranium Enrichment Center of May 10, 2007 Agreement between the Government of the Russian Federation and the Government of the Republic of Kazakhstan on cooperation in research and development in the nuclear energy sector of September 19,2017

International Treaty of Russia and Kyrgyzstan

Agreement between the Government of the Russian Federation and the Government of the Kyrgyz Republic on cooperation in the field of the peaceful use of nuclear energy of November 28, 2012

The number and subject matter of existing bilateral international agreements between Russia and other members of the EEU in the field of peaceful use of nuclear energy differ and depend on many aspects: the state's attitude to nuclear energy, the desire to develop the national nuclear energy industry, the general level of bilateral relations and the state's interest in long-term cooperation with Russia.

Russia and all members of the EEU have concluded framework agreements in the field of the peaceful use of nuclear energy, which establish common areas and mechanisms for cooperation. A special agreement with Belarus regulates the import of nuclear fuel from research reactors to Russia and the supply of fresh low-enriched nuclear fuel to Belarus.

According to agreements with Armenia and Belarus there are projects to build nuclear power units. The implementation of such projects is largely facilitated by the provision of state loans by Russia, regulated by interrelated international agreements. For Armenia, the development of nuclear energy is an alternative to meet the country's electricity needs. For Belarus, whose existing power plants allow meeting domestic electricity needs, the construction of a nuclear power plant will provide additional opportunities for exporting electricity, including the common electricity market of the EEU. Bilateral agreements allow Russia to implement projects to build and operate nuclear facilities in other countries, thereby securing Russia's position in the relevant market for the long term.

Separate agreements between Russia and Armenia, Russia and Belarus establish mechanisms for cooperation in nuclear safety, prompt early notification of a nuclear accident, and exchange of information in the field of nuclear and radiation safety.

Kazakhstan is a world leader in uranium production (annual production volume - about 20 thousand tons - about $20 \%$ of the world's production). Kazakhstan is interested in developing the nuclear industry - the implementation of projects to produce nuclear fuel and a nuclear power plant construction. Agreements aimed at implementing unique scientific and technical projects occupy a special place among the existing international treaties of Russia and Kazakhstan.

\section{Conclusion}


The development of a multilateral international treaty of the EEU and, in a broader sense, the formation of the EEU nuclear law is a matter of the distant future. At present, given the differences in the position of the parties in the global nuclear energy market, the lack of interest in the formation of a common market for nuclear energy of the EEU, it is more likely to strengthen the importance of Russia's bilateral international agreements with other members of the EEU in the nuclear energy sector.

\section{References}

1. State Corporation "Rosatom”. Accessed on: July 2, 2021. [Online]. Available: https://www.rosatom.ru/

2. K. Talus, Research Handbook on International Energy Law (Edward Elgar Publishing, 2014)

3. M. Naseem, International Energy Law. Kluwer Law International B.V. (The Netherlands, 2017)

4. O.V. Glikman, Intern. Leg. Cour. 1-2, $72-77$ (2020)

5. S.V. Zhiznin, V.M. Timokhov, Yadernye aspekty energeticheskoi diplomatii: monografiya [Nuclear aspects of energy diplomacy: a monograph] (MGIMO-University, Moscow, 2017)

6. S.A. Malinin, Mirnoe ispolzovanie atomnoi energii: mezhdunarodno-pravovye voprosy [Peaceful use of nuclear energy: international legal issues] (International Relations, Moscow, 1971)

7. A.I. Ioyrysh, A.M. Petrosyants, V.F. Petrovsky, Mezhdunarodnoe atomnoe pravo [International Nuclear Law] (Nauka, Moscow, 1987)

8. I.N. Pavlova, Energy Law, 2, 45-48 (2015)

9. E.O. Shorokhova, G.B. Polaeva, Integratsiya v sfere atomnoi energetiki kak faktor obrazovaniya obshchego energeticheskogo rynka EAES [Integration in the field of nuclear energy as a factor in the formation of the common energy market of the EEU], in Energy of Eurasia: New Trends and Prospects (IMEMO RAS, Moscow, 2016)

10. O.V.Glikman, A.U. Nazarova, Law and Admin., 21st cent., 16(1), 28-35 (2020)

11. M.S. Lizikova, Colloq. J. 5, 127-128 (2019)

12. M.N. Lysenko, Leg. Energy Forum, 3, 26-32 (2016)

13. M.N. Lysenko, Justice and Law, 7, 129-131 (2019)

14. M.S. Lizikova, Gaps in Rus. Legisl. 5, 229-233 (2018)

15. M.S. Lizikova, Entrep. Law, 4, 70-77 (2016)

16. D. Fouquet, Nuclear Policy in the EU from a Legal and Institutional Point of View, in R. Haas, L. Mez, A. Ajanovic (eds.), The Technological and Economic Future of Nuclear Power. Energiepolitik und Klimaschutz. Energy Policy and Climate Protection (Springer VS, Wiesbaden, 2019) 